Final article:

Hingley, M.K., Lindgreen, A., and Lan, C. (2008), "Development of the grocery retail market in China: a qualitative study of how foreign and domestic retailers seek to increase market share”, British Food Journal, Vol. 111, No. 1, pp. 44-55. (ISSN 0007-070X)

For full article, please contact LindgreenA@ cardiff.ac.uk

\title{
Development of the Grocery Retail Market in China:
}

\section{A Qualitative Study of How Foreign and Domestic Retailers Seek to Increase Market}

\section{Share}

\author{
Martin Hingley, Harper Adams University College ${ }^{1,2}$ \\ Adam Lindgreen, Hull University Business School ${ }^{3}$ \\ Lan Chen, Harper Adams University College ${ }^{4}$
}

${ }^{1}$ Dr. Martin Hingley, Department of Business Management and Marketing, Harper Adams University College, Newport, Shropshire, TF10 8NB, the UK. Email: mhingley@harper-adams.ac.uk. Telephone + 441952815386.

2 The authors contributed equally

${ }^{3}$ For all correspondence: Professor Adam Lindgreen, Department of Marketing and Business Strategy, Hull University Business School, Hull, HU6 7RX, the UK. Email: A.Lindgreen@hull.ac.uk. Telephone: + 441482463010 


\section{Development of the Grocery Retail Market in China:}

\section{A Qualitative Study of How Foreign and Domestic Retailers Seek to Increase Market}

\section{Share}

\section{Research paper}

Purpose: This article investigates the development of the grocery retail market in China. International retailers have been in China for more than 10 years, during which period a series of profound changes has occurred in the Chinese retail sector. International retailers introduced advanced retail techniques and managerial approaches; domestic retailers grew more sophisticated in their supply chain management. Foreign-based retailers in China can compete in hypermarket and supercentre formats because they offer higher-quality products and achieve larger economies of scale. Domestic retailers compete by operating smaller formats and maintaining good relationships with governments and local communities. However, formerly state-owned domestic retailers appear less competitive because they lack funds and adopt poor management styles. This study makes recommendations about future developments by domestic and foreign grocery retailers.

Design/methodology/approach: Qualitative study involving in-depth interviews with four retailers: Wal-Mart, Bonjour, Wu-Mart, and Jingkelong.

Findings: The findings pertain to several different themes, including consumers, business

\footnotetext{
${ }^{4}$ Lan Chen, c/o Dr. Martin Hingley.
} 
relationships and distribution centres, product lines, store formats, quality systems, and competition.

Research limitations: The study's findings are based only on four retailers.

Practical implications: A series of recommendations for both foreign-based and domestic retailers.

Originality/value of the paper: This research is among the first to investigate operator attitudes toward competition in the grocery retail market in China.

Keywords: Grocery retail market; China; foreign-based retailers; domestic retailers. 


\section{Introduction}

The development of global retailing has prompted international retailers to seek to harness potential markets worldwide. According to Dawson et al. (2003), the internationalisation of retailing is particularly fast in Asia. China has become one of the most attractive markets in the world, with retail sales valued at more than US\$628 billion and growth in excess of 9 percent each year. During the past 20 years, China's retail sales have grown by nearly 15 percent annually, making it the third largest market in the world (BusinessWeek Online, 2005; IGD, 2005a; Retail Asia, 2006). For some, it marks the most exciting grocery market and largest emerging opportunity in the world (AT Kearney, 2005).

China recently set the goal of owning Fortune 500 retail firms before 2010 and achieving greater competitiveness in its state-owned retail sector (Business-in-Asia, 2004). ACNielson, the global leader in market research, in its 2004 survey of the Chinese retail market, reveals that stores of modern retailers have increased by 35 percent, while the number of shopping malls has increased 37 percent (People's Daily Online, 2005).

Although international retailers entered the Chinese market in the early 1990s, a series of restrictions hampered the pace of their development and expansion. After 2004, the date of its accession to the World Trade Organisation (WTO), the Chinese government began to lift these restrictions gradually, and this greater liberalisation has enabled international retailers to pursue their expansion in China. In turn, these retailers have significant impacts on modern 
retailing techniques and introduced new formats into the Chinese market. At the same time, China experienced a series of economic and distribution reforms, including removing state-owned retailers from under the protection of the government. Simultaneously, domestic retailers are becoming more sophisticated, increasing the competition among foreign and domestic retailers in China.

This article investigates the grocery retail sector in China with the goal of providing some recommendations about future developments required by domestic and foreign grocery retailers. Primarily, it investigates the impact of foreign grocery chains on the Beijing market and compares the competitive advantages enjoyed by foreign and domestic grocery retailers.

\section{Literature Review}

The economic reform that has been underway for more than two decades in China aims to transform the command economy into a new hybrid system (Yuen and Shan, 2003). China, like other communist countries, previously operated a totally planned economy, in which the production and distribution of commodities were controlled by the central planning bureaus, the Ministries of Commerce and of Materials (Lavigne, 1995). In the past, most marketing and distribution channels remained state owned, and wholesaling or retailing existed merely for distribution. Because the aim of a distribution system in a planned economy is to provide goods where people need them, China engaged in limited investments in product development and innovation; product ranges were limited, and life cycles were much longer 
than they would be in a market-based economy (Dawson et al., 2003). Little incentive existed to design products to meet consumers' needs, and the concept of customer service hardly existed (Mun, 1988).

Today, China represents a semi-reformed, planned transition economy that embraces both pure capitalism and aspects of standard socialism (Lavigne, 1995). Capitalism is emerging in the service sector and small industries, but most domestic industries remain dominated by large, state-owned enterprises (Lavigne, 1995). The Chinese government calls it 'a socialist market economy with Chinese characteristics'. Retailing in China also is moving toward modernisation and economic transitions, but despite dramatic changes, China's retailers still are affected by the legacy of the command economy (Dawson et al., 2003).

Some of the changes induced since China opened to foreign investment 20 years ago include rapid economic growth by 9 percent per annum on average (IGD, 2005b). As the world's sixth-largest economy, China's purchasing power ranks second behind only the United States (OECD, 2005); it could overtake the United States as early as 2020 (IGD, 2005a). This rapid economic growth has helped create a large, affluent, middle-class Chinese consumer segment. The Chinese Academy of Social Sciences reports that the middle class constituted approximately one-fifth of the total population in 2003 but that this number should double by the year 2020. Rapid economic growth also has steadily increased consumer spending. The country's compound annual growth rate in luxury goods and key consumer markets exceeds 
10 percent, double the rate for those products in the United Kingdom (AT Kearney, 2005).

Since the grocery market opened to non-domestic retailers in the early 1990s, China has absorbed approximately US\$560 billion in foreign direct investment (The Economist, 2005). After China joined the WTO after 15 years of negotiations (Agarwal and Wu, 2004), it adopted three basic principles for its trade administration system — uniformity, transparency, and judicial reviewability — and abolished remaining restrictions, in line with a three-year timetable, to relax protective measures and encourage foreign investment. By 11 December 2004, China was fully open to international enterprises and allowed them to operate wholly owned businesses, with no more geographical restrictions.

In addition, great changes in China's food distribution system introduce both opportunities and challenges. For example, reforms caused major problems for state industries and the agricultural sector, because many industries produced foods for internal consumption only. In agricultural sectors, land under cultivation may be taken for other commercial uses (Ambler and Witzel, 2004). However, some progress, albeit slow, marks reductions in the economy's dependence on agriculture.

In turn, the Chinese retail market is influenced by various social, political, and economic factors, the most important of which may be the ageing population (IGD, 2005b). China's one-child policy has restricted birth rates during the past 50 years, yet the Chinese consumer 
base, because of the vast size of the country and the huge population, remains relatively diverse (IGD, 2005b). Even with this diversity, Chinese consumers display several common characteristics: price sensitivity, desire for convenience and quality, and a long-term orientation that encourages savings.

First, on average, Chinese consumers spend 39 percent of their incomes on food, significantly more than other developed countries, such as the United Kingdom, where average food expenditures are approximately 10 percent (Food Chain Centre, 2004). Chinese consumers tend to visit several different stores to find the merchandise with the best price. The importance of price makes it difficult for firms to cultivate patronage loyalty (Lo et al., 2001). Furthermore, the relatively poor living environment makes shopping around a leisure pursuit for Chinese consumers.

Second, the rise of the national economy has increased the wealth of Chinese consumers, who now demand more convenience and quality. Chinese women account for 46 percent of the total workforce in China-higher than in any other Asian countries and approximately the same level as in the United States. The time constraints on these working women have significant impacts on the grocery industry in the form of demands for convenience products (China-Britain Business Council, 2006).

Third, Chinese consumers usually save most of their income, because the country's social 
safety net is thin, and most people must pay for healthcare and pensions out of their own pockets (McKinsey Quarterly, 2006). Furthermore, China's cultural identity, according to Hofstede's (2001) cultural dimensions, relies heavily on a long-term orientation (LTO). Because LTO is a value based on tradition, it takes longer for foreign businesses to embed themselves into such a society.

Beyond this cultural characteristic, other features make business relationships in China unique and have attracted significant interest. For example, modern Western business practices emphasise the quality of on-going relationships rather than short-term transactions, with a particular emphasis on trust, dyadic symmetry, and mutuality (Hingley, 2005; Lindgreen, 2003). The Chinese guanxi philosophy, in contrast, refers to the social network of personal relationships a person maintains (Lovett et al., 1999), and business guanxi means developing business networks through individual guanxi relationships. This concept is governed by the equity rule (Trienekens et al., 2006), demanding 'mutual favours' between people, which is not traditionally viewed as corruption in China. Although China is working to develop its legal structure and professionalise its businesses, guanxi remains fundamental to business success, so operators must have solid networks of business and government contacts (Chee and West, 2004). Because guanxi is embedded in Chinese culture, firms need long-term relationships before starting to do business (Chee and West, 2004).

In the grocery retailing sector in particular, China remains dominated by domestic retail 
chains in terms of store numbers and turnover. A recent merger between two key domestic players, Shanghai Lianhua and Shanghai Hualian, also created a top retailer-Shanghai Bailian - that is likely to retain its top position, at least in the short term (IGD, 2005b). However, foreign retailers continue to grow. For example, Wal-Mart successfully opened seven supercentres and one Sam's Club store, and Carrefour opened 27 chain stores in five cities. Metro has established the first wholly foreign-owned wholesaler, Metro Warehouse Management, along with 15 new cash-and-carry stores (Dawson et al., 2003).

When international commercial investors first came to China, department stores were the primary choices for cooperation (Wang, 2003), but during the 1990s, China's food retail sector changed dramatically, and operators based in the Netherlands, Japan, and the United States therefore turned to China's retail market (Gilmour and Gale, 2001), focusing on new and less well-established formats, such as hypermarkets, general merchandise stores, and membership wholesale clubs (Wang, 2003). These new superstores offer extensive lines of goods from both food and non-food categories (Tambe, 2003); some even host restaurants on-site. The thriving hypermarket format has proved a booming market marked by convenience, comfort, and low prices.

\section{Methodology}

Because the aim of this study is to understand the grocery retail sector in China and make recommendations about future developments by investigating the impact of foreign grocery 
chains and the competitiveness of foreign-based and domestic grocery retailers, this research was conducted in Beijing, the capital of and the most commercial city in China. According to Tradepartner UK (2002), of all Chinese cities, Beijing earns the highest scores in terms of average gross domestic product, income, and retail sales, making it a first-tier city for foreign retailers. Although some retailers focus in other cities, such as Wal-Mart in Guangzhou and Carrefour in Shanghai, Beijing maintains the greatest diversity of retail business and offers the greatest competition in China, making it the appropriate site for our investigation.

We undertake four in-depth interviews with two foreign and two domestic retailers and thereby achieve an exploratory investigation of managerial attitudes among both Chinese and foreign grocery retailers. Because of various cultural issues, special skills are required to interview Chinese respondents; therefore, the prime interviewer is Chinese and fully understands the pertinent language, cultural, and contextual issues. The interviews follow a semi-structured guide (Patton, 1987). Each interviewed retailer has typical characteristics that make it representative of its category of grocery retailers in Beijing. Specifically, we choose a leading foreign retailer that compares with one of the leading domestic retailers in Beijing and consider foreign retailers that have growth potential similar to that of their Chinese counterparts. Of the two leading foreign retailers, Carrefour declined to be interviewed, so Wal-Mart serves as the primary foreign retailer for this research. We next describe the key characteristics of each respondent. 
One of the leading foreign food retailers in China, Wal-Mart enjoys large economies of scale and operates three major formats (supermarket, hypermarket, and convenience), with a focus on the Sam's Club (cash-and-carry) format. Wal-Mart opened its first supercentre in Shenzhen, in the south of China, in 1996, then expanded to stores in 20 provinces, including the first-tier cities Beijing and Shanghai and 18 second-tier cities. Wal-Mart received approval for wholly foreign-owned stores and employs advanced chain management and logistical controls. The Sam's Club outlet is located outside of Beijing.

Bonjour, a French food retailer that established its business in Hong Kong in 2000, runs stores in Beijing, Shanghai, Hong Kong, and Qingdao. In Beijing, the Bonjour store is located in the city centre; it operates with smaller economies of scale and employs only a supermarket format. Its operations are a joint venture with Beijing Commissariat Group Limited, with stock divided between them.

One of the leading domestic food retailers in China, Wu-Mart also enjoys large economies of scale and operates in the supermarket, hypermarket, and convenience store formats, with a primary focus on convenience stores (including mini-marts and kiosks). Located in Beijing and nearby cities (Hebei and Tianjin), Wu-Mart started as a private chain (i.e., non-state-owned enterprise).

Finally, Jingkelong is typical of domestic food retailers with small economies of scale and 
operates in three major formats (supermarket, hypermarket, and convenience). Located only in Beijing (Hebei province), this state-owned domestic chain is in the process of transforming into a commercial enterprise. Its stores appear mainly in local community areas.

\section{Discussion}

This discussion section considers the matters raised regarding retail development in China by employing comments from the in-depth interviews with the four retailers to illustrate the key issues.

Although China is the world's sixth-largest economy and has great purchasing power, a significant income gap still exists between rural area and the cities, as well as between wealthier downtown populations and suburbanites. The retailers recognize this gap, noting:

"Our store is located in the downtown area in Beijing. 50\% of our customers are under 40 years old, and $15 \%$ of them are foreign customers." (Bonjour)

As typified by this quotation, the two foreign retailers target middle- to high-class consumers in particular, whereas the domestic retailers target middle- to low-class consumers. Retail stores located in suburbs of Beijing are mostly run by domestic retailers, particularly Wu-Mart:

"Although the income of the Chinese consumer has grown rapidly, middle-class and low-class customers still make up a big proportion of the total population. Our 
supermarket and convenience stores are located in the suburbs of Beijing. Hypermarkets, which are located in the city, are targeting higher-level customers." (Wu-Mart)

The income gap also affects consumers of different ages. The sector of the population older than 45 years represents a working population that came of age before China's economic and distribution reforms. Because pension schemes at that time were undeveloped, most people receive a minimal allowance from the government each month. However, these older consumers also tend to save more than the younger population to ensure they can afford healthcare and protect themselves against other risks. In addition, in support of Hofstede's (2001) cultural profiling, consumers in Beijing tend to emphasize a LTO, in that they hope to save money for the future.

All respondents emphasised their recognition that consumers in China are very price sensitive, especially those in Beijing. Although Chinese consumers spend 39 percent of their incomes on food, the biggest disbursal of their total income, retail discounters are not popular, and the formats growing most rapidly are convenience stores and hypermarkets. Whereas American shoppers, with their easy access to private transportation and ample home storage capacities, embrace a "buy in bulk" lifestyle, most Chinese consumers do not. Furthermore, Chinese consumers, even those with lower incomes, remain conscious of food quality, particularly its freshness. Discount format retailers usually do not offer fresh meat or vegetables but provide only packaged or canned food; this offering does not match the preferences of Chinese 
consumers. In contrast, most hypermarkets and supermarkets in China provide their own in-store butcher and other counters to offer fresh food.

Chinese consumers also appear willing to try new products. In this context, Wal-Mart's 'retail-tainment' initiative, which provides new product trials and in-store activities, has been very successful, consistent with prior IGD (2005a, 2005b) findings.

The interview respondents unanimously agree that geographical differences cause divergences in taste. Consumers in the south of China prefer lighter tastes and low sugar contents, and they also consume more fruit and vegetables than do consumers in the north of China, likely due to the tropical climate. In the north, consumers tend to consume more sugar and protein to withstand the cold temperatures. Such differences confirm the suggestion that Chinese consumers are quite heterogeneous.

However, consumers in Beijing largely are aware of foreign-based food retailers, recognizing their names and promotional activities. For example,

"We gain customer confidence by telling them we are the largest retailer in the world. Some of the young shoppers really appreciate our background and drive a long way to come here." (Wal-Mart)

Such consumers are open to the idea of foreign retailers, and many enjoy shopping in foreign retail stores because they assume they sell products of higher quality. Bonjour works hard to 
maintain this perception. These image-conscious consumers will pay a premium for better products, if they can afford them. In addition, foreign-based retail stores usually provide a nicer shopping environment than domestic retail stores; Wal-Mart even set a capacity limit on its total shopping population in Sam's Club to maintain a cosy environment.

In contrast, the domestic retailers enjoy social relationships that they have built over time with local communities. Shoppers in the domestic stores tend to be older than those in the foreign-based retail stores. These outlets maintain a closeness with older customers, who have traditional and conservative values, including a preference to shop daily. Thus, domestic retailers' stores often are located within a local community. Consumers visit the stores not only to purchase food but also to exchange information with the salespeople and other consumers. They remain loyal to local brands, because they have a lifetime's worth of experience with them. The domestic retailers, which have built strong relationships with their local customers, tend to focus more on supermarket and convenience stores. Their better understanding of consumer buying patterns also enables them to operate smaller formats more effectively. Although some domestic retailers have initiated hypermarkets, the format has proven less competitive as a result of the domestic retailers' management style, lack of retail technology, and poor economies of scale.

When it comes to loyalty schemes, consumers in Beijing appear very interested. Point collection programs, which have a relatively long history in the market, remain very popular 
among domestic retailers. A new membership program offered by Wal-Mart initially was not very successful but since has been widely accepted, even though the domestic retailers that attempted similar schemes never succeeded with them. These different results may relate to the differences between Wal-Mart's membership program and the other offers; namely, Wal-Mart's system is ordered and carefully recorded, which makes it seem fair to consumers.

In line with the minimal car ownership rates in China, consumers in Beijing appreciate it when retailers provide transportation to and from a hypermarket or supercentre. Many Chinese consumers spend much of their income on transportation and communication. However, local consumers who enjoy shopping on a daily basis find no value in unnecessary transportation to larger stores.

New product lines have developed in both food and non-food sectors. Food product lines remain the mainstay in domestic retail stores, even hypermarkets and supercentres. These retailers also concentrate most of their private-label business in food products, because they enjoy supportive cooperation and strong arrangements with farmers and suppliers. However, foreign-based retailers often focus on non-food sales, which domestic retailers often cannot afford without economies of scale. Although most retailers have increased the pace of private-label product development, this sector continues to be an emerging trend in China.

For such products, most retailers, whether foreign or domestic retailers, run their own 
distribution centres that have responsibility for product packaging and other processing; some operate their food and non-food divisions separately. The foreign retailers' distribution centres cover a wider geographic area; for example, Wal-Mart's renowned distribution technology helps it reduce labour and handling costs. In contrast, distribution centres for the domestic retailers generally have limited geographic coverage and locate near the main regions of operation. The handling and labour costs are higher than those for foreign-based retailers.

Wholesale agents seldom appear in the grocery supply chain, because most foreign and domestic retailers purchase their products directly from manufacturers or a third-party delivery company (i.e., a company that subcontracts with both the retailer and the supplier to deliver goods). Foreign retailers gradually have begun to introduce the centralised and third-party contract supply chain systems that proliferate in the West (Hingley, Lindgreen, and Casswell, 2006). Some domestic retailers, especially previously state-owned food suppliers, already have direct channels to farm-level producers; they also may own the production facility. Because foreign-based retailers lack these connections, they must purchase products from supply intermediaries.

Both of the foreign retailers interviewed during our study indicate that they obtain their products by selecting among suppliers that apply to supply their retail stores. Bonjour, for example, works with 50 suppliers; other, larger chains use more than 100. In contrast, 
Wu-Mart obtains most of its suppliers by acquiring other supermarket chains. Jingkelong, which was a state-owned company, possesses its own dedicated suppliers of grocery products:

"We own the farmers and field. We order other products in large quantities from our suppliers on a yearly basis on an order form. Thus, the suppliers give us competitive prices." (Jingkelong)

Competition among the foreign-based retailers is strong, because they target populations with similar buying behaviours and income levels. Although the domestic retailers also recognise the competition in their market, it is not as strong as that among foreign retailers. None of the domestic retailers have broad economies of scale, which prevents them from operating nationally and pushes them to become leading retailers in specific regions, such as Shanghai Lianhua in Shanghai and Wu-mart in Beijing. Smaller retailers lack sufficient power to offer any real threat. In addition, the domestic retailers that never were state-owned enterprises, such as Wu-Mart, adopt managerial structures similar to those of the foreign retailers and are becoming more and more competitive. Thus, competition between these stores and foreign-based retailers likely will grow stronger in the future.

In addition to advanced management systems, foreign-based retailers often rely on quality control systems and operate according to structured, strict regulations. For example, products must attain a certain standard to be accepted and displayed in-store. Thus, we note 
competition based on quality standards among different suppliers. Most large retailers maintain quality testing facilities within their production bases and distribution centres to ensure high-quality products.

Such efforts enable the foreign-based retailers to develop strong consumer confidence. For example, some offer unconditional refunds, even without product quality problems, whereas few domestic retailers provide such guarantees. Domestic retailers therefore tend to obtain consumer confidence from their low prices rather than their quality.

When foreign retailers first entered China, the biggest difficulties they faced involved acquiring trading licenses and other approval documents. Even after China's WTO accession, many restrictions remained in place, though the Chinese government has since lifted most of them. However, specific, non-transparent problems remain for foreign companies in China. Bonjour's first major hurdle, before China joined the WTO, was to obtain the appropriate business license, but even accession to the group does not mean the end of barriers:

"There were many restrictions for us before China joined WTO; even after, the government still puts us in a difficult position." (Wal-Mart)

Today, understanding culture may be the primary problem associated with doing business in China. China has unique cultural characteristic, different even than other Asian countries. As foreign retailers begin to shift their focus to second-tier cities, they must consider the 
different buying patterns and tastes of these consumers. Expanding a business in a foreign country with a non-homogenous consumer base offers a great challenge for foreign retailers. In response, most foreign retailers now recruit their staff and most of their managers from China to gain a better understanding of Chinese culture.

Such cultural barriers present real problems in partner relationships. Most Chinese business relationships require guanxi (Trienekens, Omta, and Lu, 2006), including relationships with the provincial government and district administration. The foreign retailers thus emphasise that embedded cultural differences present the greatest difficulty in doing business in China:

"Sometimes, when you don't have good relationship-that guanxi stuff with the government or local administrative department-it makes it more difficult to operate a business in China." (Bonjour)

Yet these challenges for foreign retailers do not imply that everything is easy sailing for domestic retailers. Wu-Mart acknowledges that confronting competition from foreign retailers will represent its main challenge in the future, and Jingkelong faces a difficult transition to become a commercial and competitive organisation:

"We were a state-owned retailer; we are still transforming into a commercial retailer. It is not too difficult to transform the structure. It is difficult to transform people's ideas. For example, if a staff member made a mistake in our store, he may only be warned by his supervisor, but if the same mistake happened in a foreign store, he would be fired. 
Compared with non-state-owned retailers, we are still somehow restricted by the government." (Jingkelong)

Although these previously state-owned retailers are becoming commercial, the government still holds the majority of their stock. Each strategic implementation must receive government approval; most of the funds that support these retailers come from the government as well. The stores lack funds to develop retailing techniques or make other improvements, but without modern retail techniques, these chains cannot attain better efficiency. An inefficient network eventually will result in lost consumers. Furthermore, the staff working for these retailers usually has worked with the store since the planned economy era and is accustomed to working within the system; employees may find it difficult to adapt to changing management styles. Many consumers and employees have difficulty changing their mindsets to match the modern commercial market. In addition, guanxi remains embedded in once-state-owned retail companies, and staff members often perceive rewards and punishments as insufficient, which ultimately may damage their work motivation.

\section{Conclusions and Recommendations}

The retail market in China continues to grow, and competition in the future will likely be stronger as more international retailers enter the market and domestic retailers grow and expand. Domestic retailers likely will explore the hypermarket business whilst maintaining market growth in the convenience and supermarket formats. Foreign retailers will expand 
their businesses to second-tier cities and maintain their focus on operating hypermarket and supercentre formats.

\subsection{Recommendations for foreign-based retailers}

- Study and understand the market. Foreign retailers should invest more in market research in China to tailor their strategies to the market and reduce operational risks.

- Strengthen links to local partners. The best way of learning Chinese culture is to get along with Chinese people. China has a unique cultural environment (often specific to different regions) and a particular business etiquette. Therefore, foreign retailers should invest in developing better connections and stronger links to local companies.

- Develop a suitable training programme. One of the main strengths of foreign retailers remains their access to advanced techniques and well-developed managerial approaches to business. However, if they fail to adapt these skills, they will not fit into this totally different culture with a different social system. Chinese managers with an understanding of both Chinese culture and modern retail techniques can help companies improve their competitiveness.

- Develop a multi-format strategy. Hypermarket formats are not suitable in many regions of China. In some first-tier cities, this format is reaching saturation.

\subsection{Recommendations for domestic retailers}

- Co-operate with other retail companies. Most domestic retailers suffer from limited 
economies of scale. To resist mergers with other retailers and gain more power in the supply chain, domestic retailers should co-operate with one another.

- Develop stronger relationships with local communities. One of the main strengths of domestic retailers is their good relationships with local consumers; they should continue to develop local campaigns to strengthen these valuable relationships.

- Be willing to learn. The leading Chinese domestic retailers have become more sophisticated in terms of supply chain management and strategy implementation, but they still lack efficiency compared with leading foreign retailers. To succeed in the competitive marketplace of the future, they must remain open to new approaches.

\section{References}

Agarwal, J. and Wu, T. (2002), “China's entry to WTO: global marketing issues, impact, and implications for China”, International Marketing Review, Vol. 21, No.2, pp. 279-300.

Ambler, T. and Witzel, M. (2004), Doing Business in China, 2nd ed., Routledge, London.

AT Kearney (2005), The 2005 Global Retail Developments Index; Destination: China. http://www.atkearney.com/main.taf?p=5,3,1,108,4.

Business-in-Asia (2004), "Retail sales reach $8.5 \%$ growth; China aims to have Fortune 500 retail firms by 2010”. http://www.business-in-asia.com/china_retail2.html.

BusinesWeek Online (2005), "Let China's retail wars begin; Newly unfettered foreign chains could grab more of China's market”. http://www.businessweek.com/magazine/content/05_03/b3916063_mz014.htm. 
Chee, H. and West, C. (2004), Myths about Doing Business in China, Palgrave Macmillan, London.

China-Britain Business Council (2005), "Understanding the Complexity of the Chinese Consumer". http://www.cbbc.org/the_review/review_archive/sectors/29.html.

Dawson, J., Mukoyama, M., Sang, C. C., and Larke, R. (Eds.) (2003), The Internationalisation of Retailing in Asia: The Reform of the Distribution System in China, Routledge, New York.

Food Chain Centre (2004), "Changes in family type". http://www.foodchaincentre.com/library/UK\%20Lifestyles/Changes\%20Working\%20Pop ulation.htm.

Gilmour, B. and Gale, F. (2001), “A maturing retail sector: Wider channels for food imports? China's food and agriculture: Issues for the 21st Century/AIB-775”, USDA Economic Research Service, Washington DC.

Hingley, M. (2005), "Power to all our friends? Learning to live with imbalance in UK supplier-retailer relationships", Industrial Marketing Management, Vol. 34, No. 8, pp. 848-858.

Hingley, M, Lindgreen, A., and Casswell, B. (2006), "Supplier-retailer relationships in the UK fresh produce supply chain", Journal of International Food Products and Agribusiness Marketing, Vol. 18, No. 1/2, pp. 49-86.

Hofstede, G. (2001), Culture’s Consequences: Comparing Values, Behaviors Institutions and Organisations across Nations, 2nd ed., Sage Publications, London. 
IGD (2005a), Global Retailing, IGD Business Publication, Watford.

IGD (2005b), Retailing in China, IGD Business Publication, Watford.

Lavigne, M. (1995), The Economics of Transition: From Socialist Economy to Market Economy, Macmillan, London

Lindgreen, A. (2003), “Trust as a valuable strategic variable in relationship marketing: different types of trust and their implementation", British Food Journal, Vol. 105, No. 6, pp. $310-328$.

Lo, T. W., Lau, H. F., and Lin, G. S. (2001), "Problems and prospects of supermarket development in China”, International Journal of Retail and Distribution Management, Vol. 29, No. 2. pp. 66-75.

Lovett, S., Simmons, L. C. and Kali, R. (1999), "Guanxi versus the market: ethics and efficiency", Journal of International Business Studies, Vol. 20, No 2, pp. 231-248.

McKinsey Quarterly (2006), "The Chinese consumer: to spend or to save?" http://www.mckinserquarterly.com/article.

Mun, K. C. (1988), “Chinese retailing in a changing environment”. In: Kaynak, E. (Ed.), Transnational Retailing, Walter De Gruyter \& Co., Berlin, pp. 211-226.

OECD (2005), Review of Agricultural Policies: China, OECD, Paris.

Patton, M. Q. (1987), How to Use Qualitative Methods in Evaluation, Sage Publications, Thousand Oaks, CA.

People's Daily Online (2005), "Modern Chinese retail industry keeps sustained growth". http://english.people.com.cn/200504/19/eng20050419_181798.html. 
Retail Asia (2006), “China's retail sales shoot up $13.6 \%$ in April”. http://www.retailasiaonline.com/news/archive/june06/060602k/news4.html.

Tambe, R. (2003), Supermarkets \& Superstores, 20th ed., Key Note, Hampton.

The Economist (2005), "Survey: The insidious charms of foreign investment", Vol. 374, No. 8416.

Tradepartner UK (2002), China's Retail Market; A Report by British Chamber of Commerce in China. http://www.tradepartner.gov.uk.

Trienekens, J. H., Omta, S. W. F., and Lu, H. (2006), "Does guanxi matter for vegetable supply chains in China? A case study approach", in Proceedings of the 7th International Conference on Management in AgriFood Chains and Networks, 31 May-2 June, Wageningen University, Ede, the Netherlands.

Wang, S. (2003), "Internationalisation of retailing in China". In: Dawson, J., Mukoyama, M., Sang, C. C., and Larke, R. (Eds.), The Internationalisation of Retailing in Asia: The Reform of the Distribution System in China, Routledge, New York: pp. 155-168.

Yuen, A. and Shan, A. Y. (2003), "International transfer of retail know-how through foreign direct investment from Europe to China". In: Dawson, J. (Ed.), The Internationalisation of Retailing in Asia, Routledge, New York: pp. 137-154. 